\title{
Treatibility of Wastewater Containing 2,4 Dichlorophenol Using Aclimated Activated Sludge Microorganisms in Packed Upflow Column Bioreactor
}

\author{
Ece Ümmü Deveci* \\ Nigde Omer Halisdemir University, Engineering Faculty, Environmental Engineering Department, Central Campus, \\ Nigde, Turkey
}

Received: 6 July 2017

Accepted: 27 September 2017

\begin{abstract}
2,4-Dichlorophenol (2,4-DCP) acclimated activated sludge culture was immobilized in polyurethane foam and supplemented to a packed upflow column bioreactor (PUCB) to treat 2,4-DCP containing wastewater. The impact of sludge age and 2,4-DCP concentration on biodegradation performance were studied. Results show that sludge age affected biodegradation in the PUCB. The residence time was adjusted by feeding with synthetic wastewater without DCP. The optimum phenol concentration was determined in 5-, 10-, and 15-day-old sludge. According to the results obtained, the removal of $99 \%$ phenol and $95 \%$ COD were determined in 10-day-old sludge and $500 \mathrm{mg} / \mathrm{L}$ 2,4-DCP concentration. Packing medium was examined both visually and by SEM, and a significant amount of organisms was observed accumulating on the surface, which indicated that diffusion limitations were controlling biofilm thickness.
\end{abstract}

Keywords: 2,4-DCP biodegradation, acclimation, immobilization, packed upflow column bioreactor, polyurethane foam

\section{Introduction}

Waters containing phenol-derivative chemicals such as chlorinated hydrocarbons must be purified and discharged because of their carcinogenic and teratogenic effects, even at low concentrations. Phenol and phenolic compounds are toxic to soil ecosystems and water microecosystems, aquatic life, and plants, and have negative effects on human health even at low concentrations. They have been reported to cause liver

*e-mail: ecedeveci@gmail.com and kidney damage, cardiac toxicity, reproductive and developmental toxicity, neurotoxicity, cardiac depression, and reduced blood pressure in humans. For this reason these compounds must be removed from the environment with advanced or conventional treatment [1-2]. Phenol and chlorophenolic compounds are widely used in industry in coal businesses, coal distillation units, petroleum refining in the petrochemical industry, pulp and paper bleaching plants, resins, disinfectants, herbicide and insecticide production, and plastics production [3-4]. 2,4-DCP is 2,4-dichlorophenol or 1-hydroxy-2,4-dichlorobenzene; the molecular formula is $\mathrm{C}_{6} \mathrm{H}_{4} \mathrm{C}_{12} \mathrm{O}$ and molecular weight is $162.997 \mathrm{~g} / \mathrm{mol}$ 


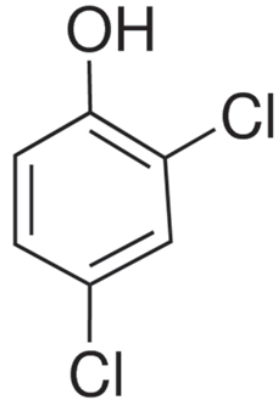

Fig. 1. 2,4-Dichlorophenol.

(Fig. 1). 2,4-DCP that has been used in the study is a type of chlorophenol, typically used in synthesizing insecticides, herbicides, preservatives, antifungal agents, and dyes [3-4]. As a result of chlorination of the phenols, as the byproducts of the hypochloritephenolic acids reactions, as biocides or as degradation products of phenoxy herbicides, chlorophenols are seen in drinking water. 2-chlorophenol, 2,4-dichlorophenol, and 2,4,6-trichlorophenol are the byproducts that have the greatest possibility of being seen in drinking water. However, in drinking water taste thresholds for chlorophenols are low [5].

Phenolic and chlorinated phenolic compounds inhibit microorganisms found in municipal biological wastewater treatment plants due to their high toxicity even at low concentrations [6]. They can easily degrade most of the pollutants that can be biodegradable due to the presence of various populations of microorganisms in activated sludge. Species that have important roles for biological degradation in activated sludge are: pseudomonas, flavobacterium, achromobacter, rhomobacterium, azobacter, micrococcus, bacillus alkaligenes, arthrobacter, ycobacterium, aeromonas, nocardia, and lophomonas. Mixed culture containing multiple microorganisms such as pure culture or activated sludge can be used for degrading chlorinated aromatic compounds [7-8]. Microorganisms such as Arthrobacter, Pseudomonas, Alcaligenes, and Phanerochaete have been reported to break down these compounds [4, 9-11]. This toxic compounds such as 2,4,6-trichlorophenol (TCP) inhibited phenol biodegradation and biomass growth. Song et al. [12] in their work on UV photolysis converted TCP into dichlorocatechol, monochlorophenol, and dichlorophenol. After UV photolysis were executed, phenol-removal and biomass-growth rates importantly gained speed. That is why after UV photolysis was executed the monod maximum specific growth rate ( $\mu$ max) increased by $9 \%$ and the half-maximumrate concentration (Ks) decreased by $36 \%$. Various bioreactors are used that are batch and continuously working in determining the biodegradation performance [7, 13-16]. In addition to conventional activated sludge systems [17], immobilized within calcium alginate gel beads for the fluidized bed bioreactor [18], jet-loop bioreactor [19], sequencing batch reactor (SBR) [20], moving bed sequencing batch reactor (MSBR) [21], and membrane biofilm bioreactor [22] are used for refining. In biofilm reactors, whether they are fluid bed or filled column reactors, plastic materials such as PVA gel [23] and polyurethane [24] or ceramic balls [9, 25] can also be preferred as filling material, as well as natural materials such as sand, clay, anthracite, and slag.

In this study, microporous polyurethane (sponge) was used as filling material for the immobilization of upflow filled column reactor and activated flour acclimated in the reactor. It was developed by feeding synthetic wastewater that does not contain 2,4-DCP to the acclimated sludge support material. The addition of 2,4-DCP was carried out after immobilization, and the bioreactor was operated in a batch system for $18 \mathrm{~h}$ hydraulic retention time. System performance was determined by chemical oxygen demand (COD), phenol concentration, and time-dependent monitoring of physical parameters. The advantages of this system are small footprint, economical packing medium, and high removal efficiency. The micro flora were protected by immobilization of the sludge, and this was able to degrade phenol concentrations over $1,000 \mathrm{mg} / \mathrm{L}$.

\section{Material and Methods}

\section{Culture}

Activated sludge cultures to be used as initial inoculant were obtained from the Greater Municipality of Kayseri Domestic Wastewater Treatment Plant. The activated sludge culture was taken from the reactor fed with synthetic wastewater free of chlorophenol and used in the first inoculum as equilibrated cultures for all experiments. Activated sludge culture growth media content is: $\mathrm{K}_{2} \mathrm{HPO}_{4}, 0.5 \mathrm{~g} / \mathrm{L}$; $\left(\mathrm{NH}_{4}\right)_{2} \mathrm{~S}_{4}, 0.94 \mathrm{~g} / \mathrm{L}$; $\mathrm{KH}_{2} \mathrm{P}_{4}, 0.25 \mathrm{~g} / \mathrm{L}$; and whey powder, $1.0 \mathrm{~g} / \mathrm{L}$. Growth medium was prepared using tap water.

The stock synthetic wastewater was prepared to contain $1 \mathrm{~g} / \mathrm{L}$ glucose, $0.1 \mathrm{~g} / \mathrm{L}$ peptone, $0.2 \mathrm{~g} / \mathrm{L}$ urea, $0.1 \mathrm{~g} / \mathrm{L}\left(\mathrm{NH}_{4}\right)_{2} \mathrm{SO}_{4}, 0.1 \mathrm{~g} / \mathrm{L} \quad \mathrm{KH}_{2} \mathrm{PO}_{4}$, and $0.01 \mathrm{~g} / \mathrm{L}$ $\mathrm{K}_{2} \mathrm{HPO}_{4}$. Micronutrients included $\mathrm{CaCl}_{2}(15 \mathrm{mg} / \mathrm{L})$, $\mathrm{MgSO}_{4} \cdot 7 \mathrm{H}_{2} \mathrm{O}(30 \mathrm{mg} / \mathrm{L}), \mathrm{CuSO}_{4} \cdot 5 \mathrm{H}_{2} \mathrm{O}(0.75 \mathrm{mg} / \mathrm{L})$, $\mathrm{FeSO}_{4} \cdot 7 \mathrm{H}_{2} \mathrm{O} \quad(15 \mathrm{mg} / \mathrm{L}), \quad \mathrm{ZnSO}_{4} 7 \mathrm{H}_{2} \mathrm{O} \quad(0.5 \mathrm{mg} / \mathrm{L})$, $\mathrm{MnSO}_{4} \cdot 7 \mathrm{H}_{2} \mathrm{O}(30 \mathrm{mg} / \mathrm{L})$, Citric Acid $(60 \mathrm{mg} / \mathrm{L})$, $\left(\mathrm{NH}_{4}\right)_{6} \mathrm{Mo}_{7} \mathrm{O}_{24} \cdot 4 \mathrm{H}_{2} \mathrm{O} \quad(0.5 \mathrm{mg} / \mathrm{L}), \mathrm{H}_{3} \mathrm{BO}_{3}(0.01 \mathrm{mg} / \mathrm{L})$, and $\mathrm{KI}(0.01 \mathrm{mg} / \mathrm{L}) . \mathrm{NaHCO}_{3}$ was used as buffer to adjust the influent $\mathrm{pH}$ to $6.8 \pm 0.2$. All the chemicals were of analytical grade. In the acclimation incubation, the sludge had $2,000 \pm 24 \mathrm{mg} / \mathrm{L}$ mixed liquor volatile suspended solids (MLVSS). The acclimation study was carried out at a working volume of $100 \mathrm{~mL}$ in a $250 \mathrm{~mL}$ Erlenmeyer in a shaking incubator. The incubation was completed by treating the 5-, 10-, and 15-day-old sludge with $250 \mathrm{mg} / \mathrm{L} 2$-DCP following 2,4-DCP (linear formula $\mathrm{CI}_{2} \mathrm{C}_{6} \mathrm{H}_{3} \mathrm{OH}$, molecular weight 163.00, CAS number 120-83-2) (2-DCP) small stepwise 


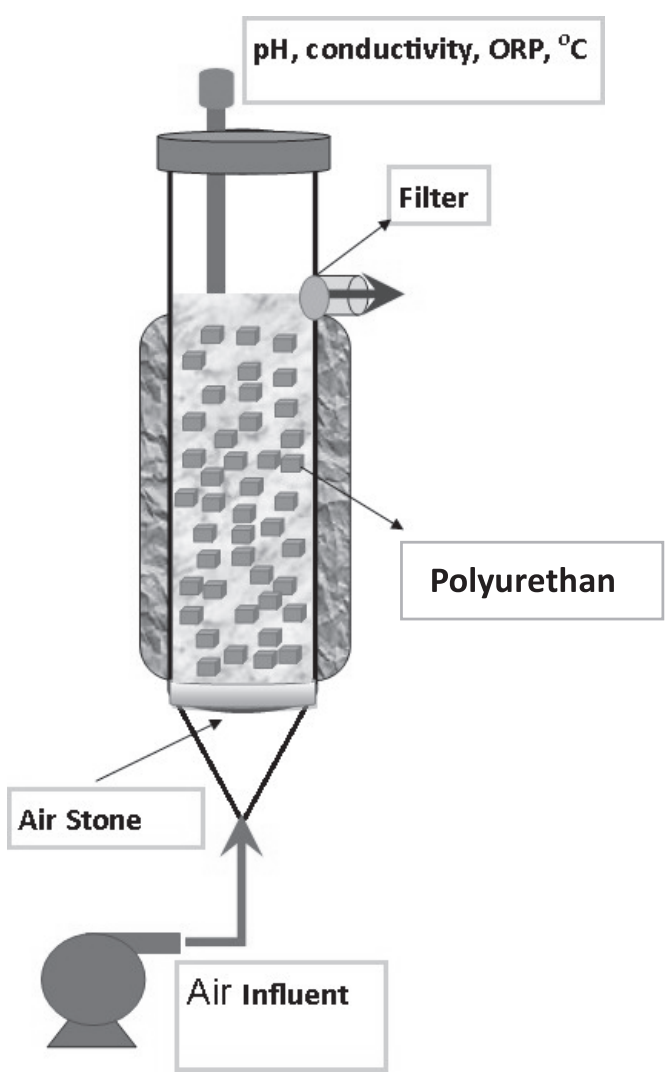

Fig. 2. PUCB used in the study.

increments, during 4 weeks. Synthetic chlorophenolic wastewater was prepared by dissolving $0.4 \mathrm{~g} / \mathrm{L} \mathrm{NaOH}$ in $1 \mathrm{~L}$ distilled water and adding $5 \mathrm{~g} / \mathrm{L}$ 2,4-DCP (Merck). All acclimation incubation was operated at $25^{\circ} \mathrm{C}$ and aeration was provided at $200 \mathrm{rpm}$ shaking.

Active sludge is used for the immobilized and suspended column bioreactor. In the immobilized bioreactor, the biomass's adsorption and proliferation on the porous packing medium could be noticed visually due to its being faster. At the end of day 10, all of the

Table 1. Operational PUCB parameters.

\begin{tabular}{|c|c|}
\hline Operational parameter & Value \\
\hline Detention time (with packing) & 18 hours \\
\hline Air flow rate & $2 \mathrm{~L} / \mathrm{min}$ \\
\hline Operating temperature & $25 \pm 1^{\circ} \mathrm{C}$ \\
\hline Packing media (foam) pore size (average) & $295 \mu \mathrm{m}$ \\
\hline Size of foam pieces & $0.5 \times 0.5 \mathrm{~cm}$ \\
\hline Porosity & 0.8 \\
\hline Water sorption capacity of the media & $8.17 \mathrm{~g} / \mathrm{g}$ \\
\hline Total column height & $52 \mathrm{~cm}$ \\
\hline Total packing media height & $38 \mathrm{~cm}$ \\
\hline Port - height from base (exit port) & $38 \mathrm{~cm}$ \\
\hline
\end{tabular}

packing medium was covered with biofilm. Following immobilization, synthetic wastewater was filled into the system and the solution was re-circulated in batch mode for 10 days. And the bioreactor was run in continuous mode when COD removal reached a value of $97 \%$ (based on the initial COD concentration). The $\mathrm{pH}$ levels were kept at $6.5 \pm 0.5$ on a daily basis by monitoring. With a scanning electron microscope (SEM) (ZEISS EVO 40 EP Electron microscope), the samples of polyurethane foam were examined during the immobilization of the culture. $3.0 \%$ glutaraldehyde in $0.1 \mathrm{M}$ phosphate buffer was used to fix the foam samples at $\mathrm{pH} 7.2$, and the samples were dehydrated with ethanol $(95 \%)$ and dried at $65^{\circ} \mathrm{C}$. Before examination with SEM, the samples were coated with gold [26].

\section{Optimization Study}

An optimization study planned for the disintegration of phenolic compounds of acclimated sludge cultures was carried out in both a laboratory-scale aerated up-flow packed column bioreactor and a suspended column bioreactor, with the reactor volume of $1,000 \mathrm{~mL}$, working volume of $750 \mathrm{~mL}, \mathrm{pH}$ of $6.5 \pm 0.5$ and temperature of $24 \pm 2^{\circ} \mathrm{C}$ (Fig. 2). Aeration in the reactor is provided by adjustable aquarium pumps with the air flow of $2 \mathrm{~L} / \mathrm{min}$. A coarse bubble diffuser was located at the base of the column and through it, and the bioreactor was aerated. The operating conditions of the bioreactors are presented in Table 1. The study was carried out with 5-, 10-, and 15-day-old sludge cultures at different concentrations of 2,4-DCP in the range $100-1,000 \mathrm{mg} / \mathrm{L}$.

Within the scope of this study, the optimum sludge and phenol concentrations were determined by examining the removal efficiency of the age of the sludge and various phenol concentrations in the filled column.

\section{Analytical Methods}

For determining COD and phenol, samples from the bioreactors are filtered through membrane filters having a pore size of $0.45 \mu \mathrm{m}$ after centrifugation (8 min at 15,000 rpm). $\mathrm{pH}$, conductivity, dissolved oxygen, and ORP were directly monitored by a multimeter in bioreactors. This was done according to $\mathrm{pH}$, conductivity, dissolved oxygen, ORP, and standard methods [27-28]. Total phenol determined that the absorbance of the colored complex of phenol and p-nitroaniline was read at $470 \mathrm{~nm}$ [29]. The COD was analyzed using a thermoreactor (Giant QBH2) by closed reflux method using potassium dichromate solution as oxidant according to standard methods [30]. The COD and phenol analyses were done triple times and their average values were used afterward. 


\section{Results and Discussion}

\section{Effect of Initial Phenol Concentration on 2,4-DCP Removal}

In this work, two bioreactors (suspended and PUCB) were used and optimum conditions for the increase of synthetic wastewater containing synthetic 2,4-DCP in the acclimated activated sludge microorganisms in both reactors were determined. Activated sludge microorganisms used in the study were immobilized to microporous polyurethane material. The hydraulic retention time of the bioreactor was identified to be 18 hours in order to determine the initial phenol concentration. The result in the suspended bioreactor was worse than the PUCB. Therefore, it only gave up flow-packed column bioreactor results in this study.

As seen in Fig. 3, the initial phenol concentration is quite effective in the biodegradation of 2,4- DCP. According to the results of the hour 8 of hydraulic retention time, $100 \mathrm{mg} / \mathrm{L}$ COD removal was found to be $98 \%$, phenol removal was found to be $99 \%, 250 \mathrm{mg} / \mathrm{L}$ COD removal was found to be $96 \%$, phenol removal was found to be $99 \%, 500 \mathrm{mg} / \mathrm{L}$ COD removal was found to be $97 \%$, total phenol removal was found to be
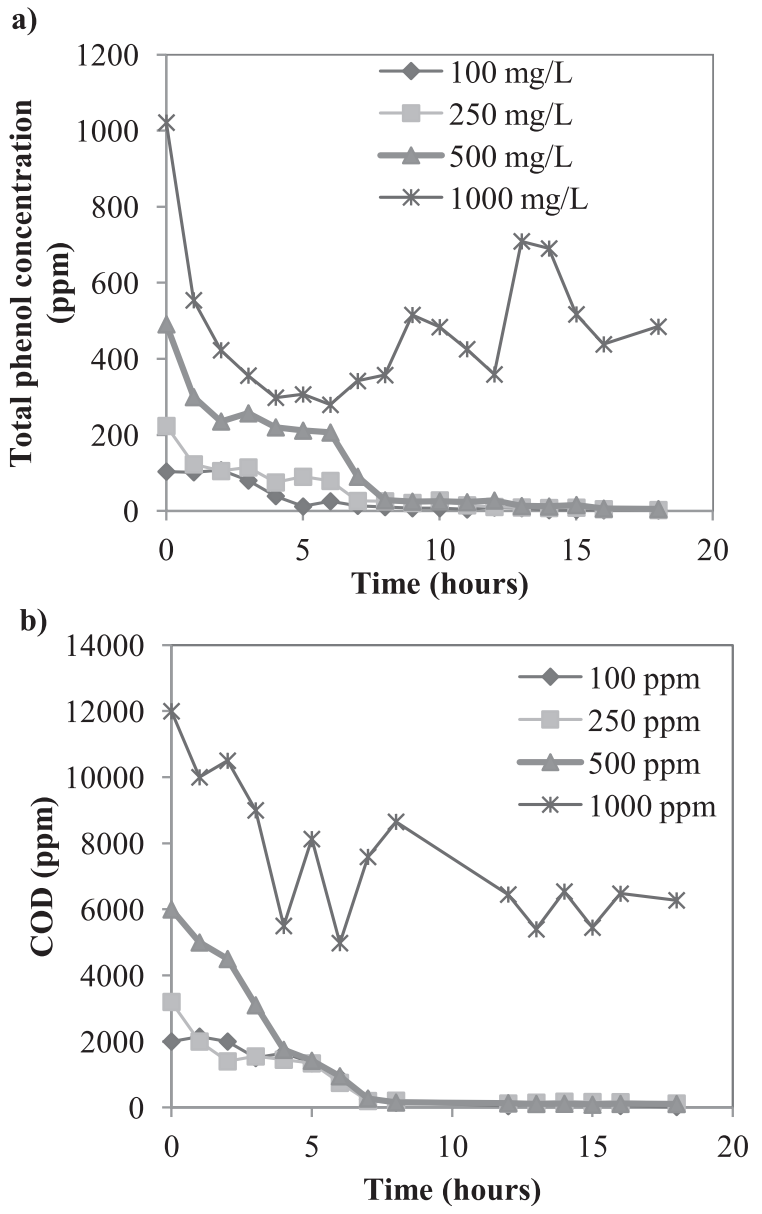

Fig. 3. Effect of initial phenol concentration on 2,4-DCP removal in upflow: a) total phenol change and b) COD change.
$99 \%, 1,000 \mathrm{mg} / \mathrm{L}$ COD removal was found to be $48 \%$, and phenol removal was found to be $52 \%$. At 18 -hour retention time, $99 \%$ of 2 close COD and phenol removal were achieved except for $1,000 \mathrm{mg} / \mathrm{L} 2,4$ DCP. The results of suspended bioreactor of hour 8 of hydraulic retention time, $100 \mathrm{mg} / \mathrm{L}$ COD removal was found to be $58 \%$, phenol removal was found to be $79 \%, 250 \mathrm{mg} / \mathrm{L}$ COD removal was found to be $56 \%$, phenol removal was found to be $71 \%, 500 \mathrm{mg} / \mathrm{L}$ COD removal was found to
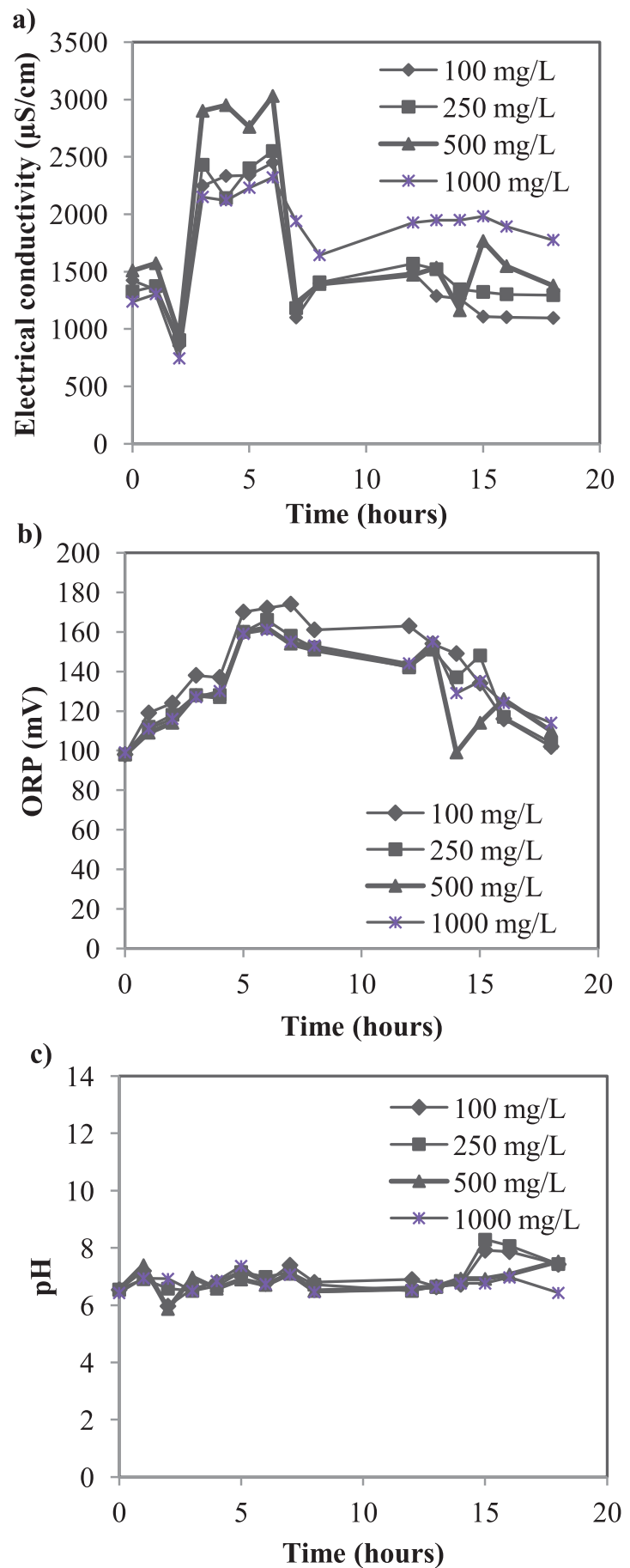

Fig. 4. Effect of initial phenol concentration on 2,4-chlorophenol removal (sludge age 10 days): a) electrical conductivity, b) ORP, and c) $\mathrm{pH}$. 
be $66 \%$, total phenol removal was found to be $64 \%$, and $1,000 \mathrm{mg} / \mathrm{L}$ COD removal was found to be $43 \%$, phenol removal was found to be $45 \%$. At 18 hour retention time, $99 \%$ of 2 close COD and phenol removal in upflow packed bioreactor and approximately $65 \%$ were achieved except for $1,000 \mathrm{mg} / \mathrm{L} 2,4 \mathrm{DCP}$. According to the results obtained, the phenol toxicity level of confined microorganisms was determined as $500 \mathrm{mg} / \mathrm{L}$. As the phenol has a toxic effect over $500 \mathrm{mg} / \mathrm{L}$, the removal rate is considerably reduced.

The effect of physical parameters in determining the effect of initial 2,4-DCP concentration on removal was monitored. According to the obtained results, it was determined that $\mathrm{pH}$ value did not change significantly, but the electrical conductivity value showed a significant change in the time interval when the biodegradation was intense and the ORP value reached the highest values during degradation (Fig. 4). The time of biodegradation that the incubation partially completed is 7-8 hours, as can be seen from Fig. 3. [30] concluded that measurements of conductivity and turbidity can be used to estimate the COD of wastewater to some extent. Acclimated activated sludge microorganisms can also complete biodegradation in a shorter time, also with the effect of immobilization. Abuhamed et al. [31] studied the biodegradation of Pseudomonas putida F1ATCC 700007 with benzene toluene and phenol in an aerobic reactor. In the study they showed that biodegradation is shorter in acclimated cultures than in non-acclimated cultures. The acclimated microorganisms degraded in 6 hours while the non-acclimated $90 \mathrm{mg} / \mathrm{L}$ benzene and toluene-containing wastewater degraded in 24 hours. Jiang et al. [32] conducted a phenol removal study with Alcaligenes faecalis. During the latter phase of the exponential growth stages, where $1,600 \mathrm{mg} \mathrm{L}^{-1}$ phenol was completely degraded in 76 hours, maximum phenol degradation was observed. A large quantity of phenol hydroxylase was secreted and accumulated by A. faecalis in this physiological phase. Then the cells were able to quickly utilize the phenol solely as a carbon and energy source. Unlike other studies, changes in physical parameters have also been associated with this study. This important change can be caused by biodegradation and by-products because similar fluctuations were observed in the same periods, even at different rates in each parameter. Furthermore, when time-dependent changes in COD and phenol removal are evaluated together, physical parameters also show a change in the same time interval.

The results presented in this paper showed that the maximum concentration of 2,4-DCP was $500 \mathrm{mg} / 1$ in immobilized bioreactors and suspended column bioreactors. 2,4-DCP removal efficiency is $95 \%$ in an up-flow packed column bioreactor an $66 \%$ in a suspended column bioreactor. Compared with other studies, the minimal inhibitory concentration of 2,4-DCP to $125 \mathrm{mg} / \mathrm{l}$ for P. putida and for P. alcaligenes was $220 \mathrm{mg} / \mathrm{l}$ [33]. Şahinkaya and Dilek [34] showed that un-acclimated and acclimated activated sludges were examined for their ability to degrade 4-CP (4-chlorophenol) using aerobic batch reactors. According to results obtained, a considerable decrease was observed in the un-acclimated culture, while the increase in 4-CP concentration up to $300 \mathrm{mg} / \mathrm{L}$ had no adverse effect on the acclimated culture's COD removal efficiency. In this study, acclimated sludge using a PUCB were able to remove $500 \mathrm{mg} / \mathrm{L} \mathrm{2,4-DCP.}$ Lin has shown that the removal efficiency for $2,4-\mathrm{DCP}$ was $\sim 89 \%$ in a steady-state condition [9]. Patel and Kumar (2015) indicated that Bacillus endophyticus
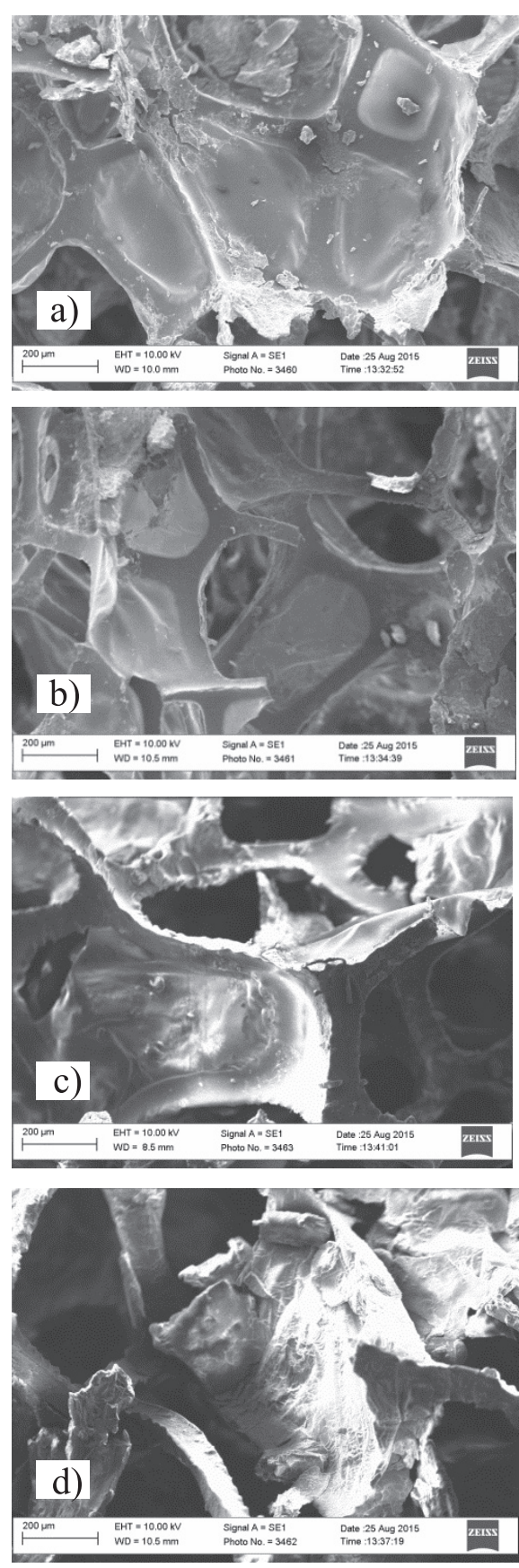

Fig. 5. SEM micrographs of immobilized active sludge biofilm from the bioreactor: a) $100 \mathrm{mg} / \mathrm{L}$ 2,4-DCP, b) $250 \mathrm{mg} / \mathrm{L}$ 2,4-DCP, c) $500 \mathrm{mg} / \mathrm{L} 2,4-\mathrm{DCP}, \mathrm{d}$ ) 1,000 mg/L 2,4-DCP (sludge age 10 days, $\mathrm{pH} 7.02 \pm 0.5,25^{\circ} \mathrm{C}$ ). 
strain degraded $400 \mathrm{mg} / \mathrm{L}$ 2,4-DCP for optimizing experimental parameters. Optimization of experimental parameters was determined using response surface methodology [35].

This work is a biological system with a significant advantage with its economical packing medium content. For the immobilization of activated sludge culture, polyurethane foam can be considered as an alternative sustainable media for bioreactors due to its suitable characteristic. However, the bioreactors, which utilize biofilms (i.e., immobilized cultures), have some operational difficulties. Biofilm loses its integrity as it matures. Thus, the biosolids should be removed periodically. This might be done either by restarting the system or with a backwash step to allow detachment and removal of the biomass from the packing medium. Once the biofilm is detached, it will be able to be separated easily from the packing media while losing its integrity, with its dewatering ability and due to its containing concentrated forms of biosolids. As the media has a flexible and light nature, it feeds the flows and allows the packing to be adjusted for possible short circuits of the air $[26,36]$. SEM images of polyurethane in determining the effect of 2,4-DCP concentration on the treatability at hour 8 of incubation were given in Fig. 5, which shows how the increase in 2,4-DCP concentration affected biofilm formation. A concentration of $1,000 \mathrm{mg} / \mathrm{L}$ 2,4-DCP reduced biofilm thickness and width. For this reason, $500 \mathrm{mg} / \mathrm{L} \mathrm{2,4-DCP}$ is optimum concentration for microbial activity and toxicity.

\section{Effect of Sludge Age on Chlorophenol Removal}

Five-, 10-, and 15-day-old sludges were used to determine the effect of sludge age on phenol removal. The concentration used was $500 \mathrm{mg} / \mathrm{L}$ for 2,4-chlorophenol in the incubation medium. Total phenol, COD, electrical conductivity, $\mathrm{pH}$, and ORP analyses were performed on the samples taken at every hour during incubation. The time-dependent changes of phenol and COD results from the obtained data are given in Fig. 5.

As can be seen in Fig. 6, sludge is quite effective in the biodegradation of 2,4-DCP. Although it is observed that older cells are more resistant than younger cells, 10-day-old cells are observed to be more capable of biodegradation. According to the obtained results, the chlorophenol removal by the sludge age is observed as follows: in the up-flow packed column bioreactor for 5-day-old sludge COD removal is $83 \%$ and total phenol removal is $85 \%$, for 10 -day-old sludge COD removal is $95 \%$ and total phenol removal is $99 \%$, for 15 -day-old sludge COD removal is $53 \%$ and total phenol removal is $79 \%$; and in the suspended column bioreactor for 5 -day-old sludge COD removal is $61 \%$ and total phenol removal is $64 \%$, for 10 -day-old sludge COD removal is $70 \%$ and total phenol removal is $75 \%$, and for 15 -day-old sludge COD removal is $34 \%$ and total phenol removal is $42 \%$. In the study of Quan et al. [37], 2,4-DCP degrading mixed culture was immobilized in polyvinyl alcohol gel beads, and for treating the wastewater that contained 2,4-DCP they were supplemented by sequencing batch reactors (SBR). They have studied the effects of the bioaugmentation level on the performance of bioaugmented systems. According to the results, the inoculum sizes have affected the start-up times of the SBR systems. Nine days were needed for the non-augmented SBR system to start-up; while it only took six, four, three, and two days for the SBRs with $1.9 \%, 3.7 \%, 5.6 \%$, and $9.3 \%$ immobilized cultures, respectively. In this study, sludge age was determined as 10 days. Karg1 and Eker [38] used sludge with sludge ages for 5-30 days and according to the results obtained they found that as the sludge age increased, COD and toxicity decreased. The study emphasizes that sludge age is important in the removal of 2,4-DCP. Under the experimental conditions, when a sludge of 25 days age was tested the results were: more than 90\% COD and nearly $100 \%$ DCP and toxicity removal with an SVI value of $108 \mathrm{ml} \mathrm{g}^{-1}$. In another study of Kargi and Eker [39], with a hybrid-loop bioreactor system consisting of a packed column biofilm and an aerated tank bioreactor with $400 \mathrm{mg} / \mathrm{L} 3$-chlorophenol, 20 days of sludge age and $90 \%$ removal were identified. In this study, on day

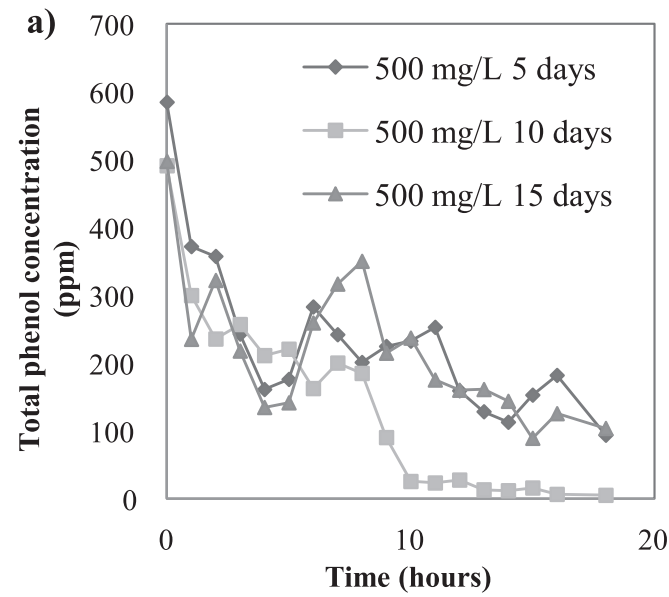

b)

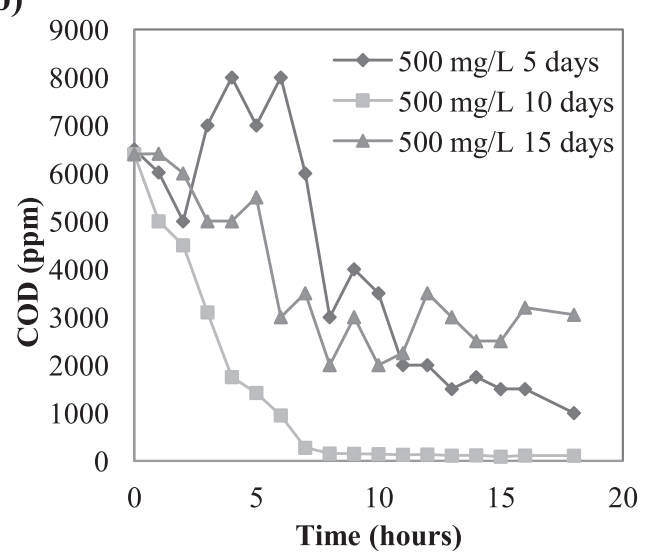

Fig. 6. Effect of sludge age on 2,4-DCP removal: a) total phenol change, b) COD change. 
10, which was determined as optimum sludge age, $99 \%$ 2,4-DCP and 95\% COD removal were determined.

$\mathrm{pH}$, electrical conductivity, and ORP analyses were carried out at regular intervals during the determination of the effect of sludge age on 2,4-DCP removal in an up-flow packed column bioreactor (Fig. 7). According to the obtained results, it was observed that $\mathrm{pH}$ value did not change significantly but that electrical conductivity value showed a significant change in the time interval when biodegradation was intense, and the ORP value decreased after degradation At hour 8, which was determined as optimum hydraulic retention
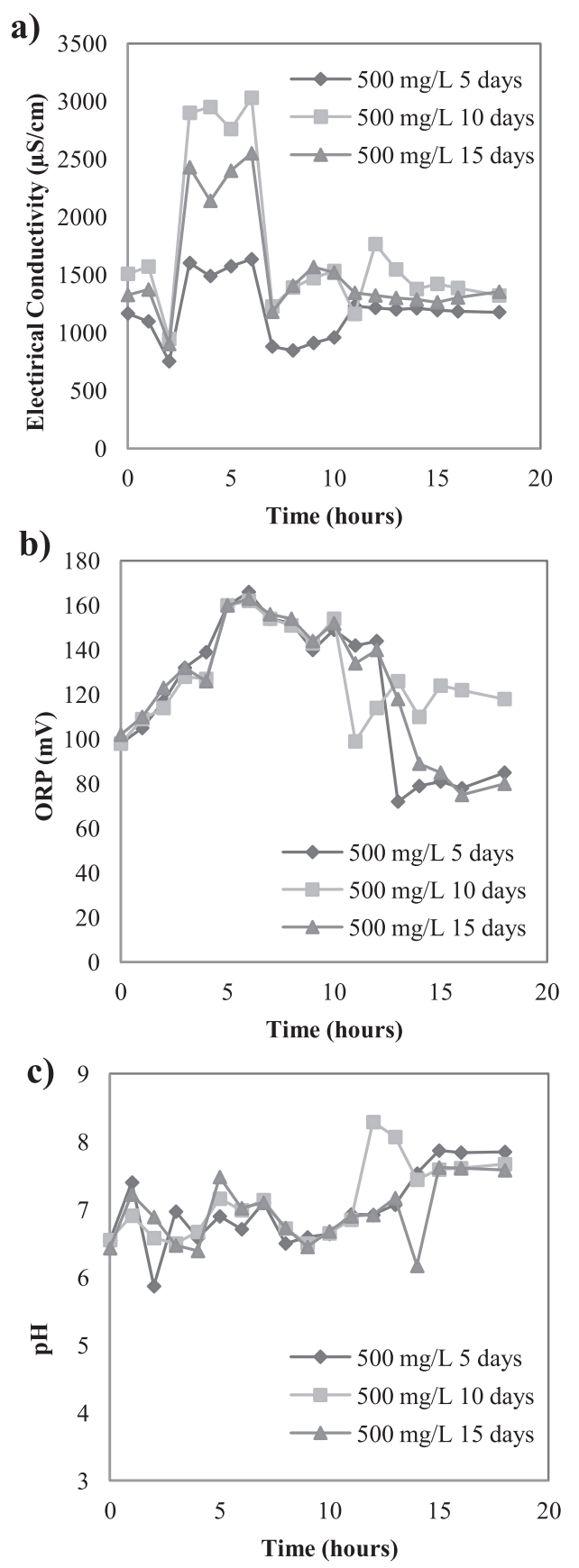

Fig. 7. Effect of sludge age on 2,4-DCP removal (2,4-DCP concentration $500 \mathrm{mg} / \mathrm{L}$ ): a) electrical conductivity, b) ORP, and c) $\mathrm{pH}$. time, conductivity and ORP reached a certain balance. COD removal and phenol removal were parallel to each other at hour 8, which was determined as the optimal 2,4-DCP degradation time. Uysal and Turkman [40] studied the effect of surfactants on the biodegradation of 2,4-DCP by activated sludge microorganisms. It has been determined in the study that microorganisms that are acclimated degrade more efficiently than non-microorganisms, and that the surfactant has positive effects on removal efficiency. The DCP removal efficiency was determined to be in the range of $97.4-97.7 \%$ for $30 \mathrm{mg} / \mathrm{L}$ phenol and $99.7-99.8 \%$ for $100 \mathrm{mg} / \mathrm{L}$ phenol. It has been determined in the study that sludge age is effective in phenol removal and that older cells are more efficient due to their toxicity levels. Sludge age was determined to be 10 days in the study we conducted.

Microporous polyurethane (sponge) is preferred as an immobilization material due to its easy supply

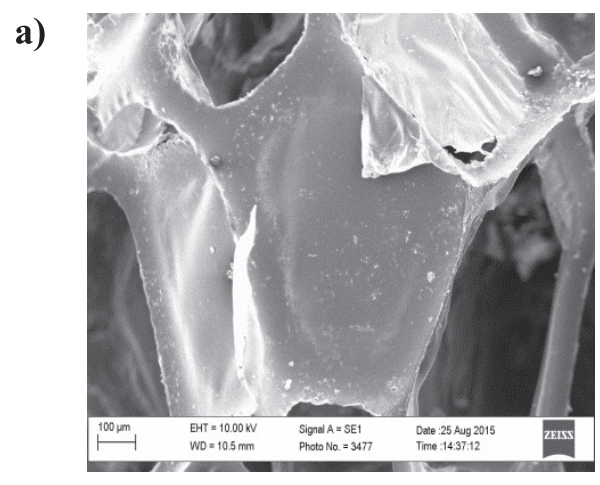

b)

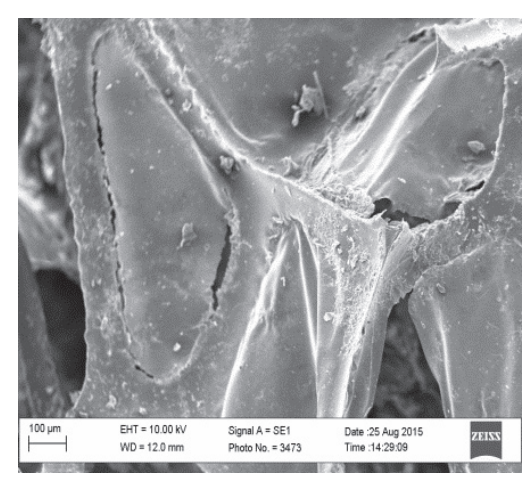

c)

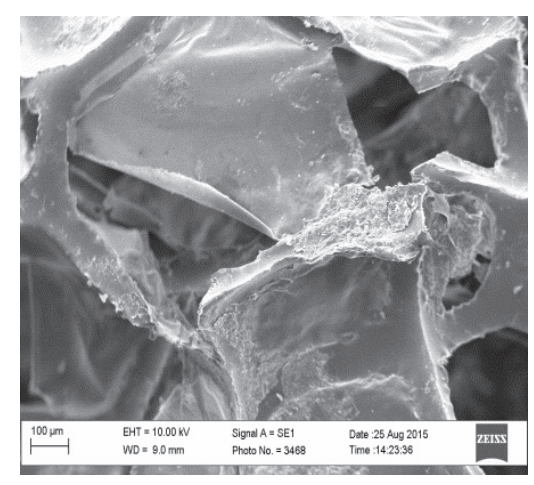

Fig. 8. SEM image of the immobilized material polyurethane used in the study: a) sludge age 5 days, b) sludge age 10 days, and c) sludge age 15 days) (500 ppm 2,4-DCP, pH 7.02 \pm 0.5 . 
availability and low cost. The polyurethane material taken from the $500 \mathrm{mg} / \mathrm{L}$ 2,4-DCP optimization medium, which is determined as the optimum condition to determine the biofilm thickness on the microporous polyurethane at a certain level, is imaged in SEM (scanning electron microscope) and the images are given in Fig. 8. When SEM images are compared, it is seen that older cells in Fig. 8c) have a thinner film thickness and more breaks from the immobilization material, suggesting that 10 days is the optimum sludge age at 2,4-DCP removal. According to the images obtained, we determined that biofilm thickness was formed up to a certain level and immobilization was achieved in the experimental work.

\section{Conclusions}

In our study, 2,4-DCP removal was carried out with microporous polyurethane (sponge) immobilization material and acclimated active sludge. Even with very toxic 2,4-DCP we accomplished 95\% COD removal.

Experiments were conducted to determine optimal parameters for 10-day sludge age at 18 hours of hydraulic retention time and at $500 \mathrm{mg} / \mathrm{L} 2,4-\mathrm{DCP}$ concentration to provide 95\% COD and 99\% 2,4-DCP removal. As the initial concentrations of $100 \mathrm{mg} / \mathrm{L}$, $250 \mathrm{mg} / \mathrm{L}, 500 \mathrm{mg} / \mathrm{L}$, and $1,000 \mathrm{mg} / \mathrm{L}$ 2,4-DCP increased, 2,4-DCP and COD removal efficiencies were obtained effectively until $500 \mathrm{mg} / \mathrm{L}$ 2,4-DCP. At concentrations higher than $500 \mathrm{mg} / \mathrm{L} 2,4-\mathrm{DCP}$, the removal efficiency is considerably reduced. This is an important result for the removal of 2,4-DCP and it can be supported by several advanced oxidation processes, indicating that the removal can be taken to $\mu \mathrm{g} / \mathrm{L}$ levels.

On the other hand, in this study it was emphasized that physical parameters such as electrical conductivity, ORP, and $\mathrm{pH}$ are important besides COD and phenol analysis in monitoring biodegradation. The significant change in electrical conductivity at the time of incubation, where biodegradation is intense, adds specificity to the study.

In addition to being an economical and easily available immobilization material and an alternative filling material option, the system can be considered to be feasible with the positive effect of immobilization on the treatment. Polyurethane is a cheap and easily supplied material. It has been determined that the material is suitable for immobilization and that it can easily be attached to the biofilm polyurethane and has an important effect on the efficiency of the treatment.

\section{Acknowledgements}

The authors thanks the Scientific Research Project of Nigde Omer Halisdemir University for financial support (project No. FEB2012/24).

\section{References}

1. HUANG D.L., WANG C., XU P., ZENG G.M., LU B.A., LI N.J., HUANG C., LAI C., ZHAO M H., XU J.J., LUO X.Y. A coupled photocatalytic-biological process for phenol degradation in the Phanerochaete chrysosporium-oxalate$\mathrm{Fe}_{3} \mathrm{O}_{4}$ system, Int Biodeter Biodegr. 97, 115, 2015.

2. BERA S., ROY A.S., MOHANTY K. Biodegradation of phenol by a native mixed bacterial culture isolated from crude oil contaminated site, Int Biodeter Biodegr. 121, 107, 2017.

3. HAMITOUCHE A., AMRANE A., BENDJAMA Z., KAOUAH F. Effect of the Ammonium Chloride Concentration on the Mineral Medium Composition Biodegradation of Phenol by a Microbial Consortium, Int J Environ Res. 4 (4), 849, 2010.

4. LIU Y.J., ZHANG A.N., WANG X.C. Biodegradation of phenol by using free and immobilized cells of Acinetobacter sp XA05 and Sphingomonas sp FG03, Biochem Eng J. 44 (2-3), 187, 2009.

5. LI J.H., WANG W., MOE B., WANG H.L., LI X.F. Chemical and Toxicological Characterization of Halobenzoquinones, an Emerging Class of Disinfection Byproducts, Chem Res Toxicol. 28 (3), 306, 2015.

6. LIU Y.J., NIKOLAUSZ M., WANG X.C. Biodegradation and detoxication of phenol by using free and immobilized cells of Acinetobacter sp XA05 and Sphingomonas sp FG03, J Environ Sci Heal A. 44 (2), 130, 2009.

7. PRAMPARO L., SUAREZ-OJEDA M.E., PEREZ J., CARRERA J. Kinetics of aerobic biodegradation of dihydroxybenzenes by a p-nitrophenol-degrading activated sludge, Bioresource Technol. 11, 057, 2012.

8. BAJAJ M., GALLERT C., WINTER J. Phenol degradation kinetics of an aerobic mixed culture, Biochem Eng J. 46 (2), 205, 2009.

9. LIN Y.H. Biodegradation of 2,4-Dichlorophenol by Mixed Culture in an Aerobic Fixed-Biofilm Process-Kinetic Model and Reactor Performance, Environ Eng Sci. 32 (6), 516, 2015

10. HUANG Z.Z., CHEN G.Q., ZENG G.M., GUO Z., HE K., HU L., WU J., ZHANG L.H., ZHU Y., SONG Z.X. Toxicity mechanisms and synergies of silver nanoparticles in 2,4-dichlorophenol degradation by Phanerochaete chrysosporium, J Hazard Mater. 321, 37, 2017.

11. SINGH B., SINGH K. Microbial degradation of herbicides, Crit Rev Microbiol. 42 (2), 245, 2016

12. SONG J.X., WANG W.B., LI R.J., ZHU J., ZHANG Y.M., LIU R., RITTMANN B.E. UV photolysis for enhanced phenol biodegradation in the presence of 2,4,6-trichlorophenol (TCP), Biodegradation. 27 (1), 59, 2016.

13. SARAVANAN P., PAKSHIRAJAN K., SAHA P. Biodegradation kinetics of phenol by predominantly Pseudomonas sp in a batch shake flask, Desalin Water Treat. 36 (1-3), 99, 2011.

14. KOBAYASHI F., DAIDAI M., SUZUKI N., NAKAMURA Y. Degradation of phenol in seawater using a novel microorganism isolated from the intestine of Aplysia kurodai, Int Biodeter Biodegr. 59 (3), 252, 2007.

15. ZHAO G.Z., ZHOU L.C., LI Y.F., LIU X.X., REN X.J., LIU X.L. Enhancement of phenol degradation using immobilized microorganisms and organic modified montmorillonite in a two-phase partitioning bioreactor, $\mathrm{J}$ Hazard Mater. 169 (1-3), 402, 2009. 
16. NUHOGLU A., YALCIN B. Modelling of phenol removal in a batch reactor, Process Biochem. 40 (3-4), 1233, 2005.

17. MA F., GUO J.B., ZHAO L.J., CHANG C.C., CUI D. Application of bioaugmentation to improve the activated sludge system into the contact oxidation system treating petrochemical wastewater, Bioresource Technol. 100 (2), 597, 2009.

18. GONZALEZ G., HERRERA M.G., GARCIA M.T., PENA M.M. Biodegradation of phenol in a continuous process: comparative study of stirred tank and fluidized-bed bioreactors, Bioresource Technol. 76 (3), 245, 2001.

19. UCUN H., YILDIZ E., NUHOGLU A. Phenol biodegradation in a batch jet loop bioreactor (JLB): Kinetics study and $\mathrm{pH}$ variation, Bioresource Technol. 101 (9), 2965, 2010.

20. YUSOFF N., ONG S.A., HO L.N., WONG Y.S., SAAD F.N. M., KHALIK W., LEE S.L. Evaluation of biodegradation process: Comparative study between suspended and hybrid microorganism growth system in sequencing batch reactor (SBR) for removal of phenol, Biochem Eng J. 115, 14, 2016.

21. MOUSSAVI G., MOHSENI M. The treatment of waste air containing phenol vapors in biotrickling filter, Chemosphere. 72 (11), 1649, 2008.

22. GOMEZ M., MURCIA M.D., ORTEGA S., BARBOSA D.S., VAYA G., HIDALGO A.M. Removal of 4-chlorophenol in a continuous membrane bioreactor using different commercial peroxidases, Desalin Water Treat. 37 (1-3), 97, 2012

23. AL-ZUHAIR S., EL-NAAS M. Immobilization of Pseudomonas putida in PVA gel particles for the biodegradation of phenol at high concentrations, Biochem Eng J. 56 (1-2), 46, 2011.

24. WANG X., RUCKENSTEIN E. Immobilization of Phanerochaete-Chrysosporium on Porous Polyurethane Particles with Application to Biodegradation of 2-Chlorophenol, Biotechnol Tech. 8 (5), 339, 1994.

25. PATEL B.P., KUMAR A. Biodegradation of 2,4-dichlorophenol in Packed-Bed Biofilm Reactor: Effect of Hydraulic Retention Time, Biogenic Substrate, and Loading Rate, Water Environ Res. 88 (12), 2191, 2016.

26. DIZGE N., TANSEL B., SIZIRICI B. Process intensification with a hybrid system: A tubular packed bed bioreactor with immobilized activated sludge culture coupled with membrane filtration, Chem Eng Process. 50 (8), 766, 2011.

27. EATON A.D., CLESCERI L.S., RICE E.W., GREENBERG A.E. Standard Methods for the Examination of Water and Wastewater (21 st ed.), American Public Health Association (APHA), American Water Works Association
(AWWA), Water Environment Federation (WEF) Washington D.C., USA, pages 2005.

28. TIEN C.J., HUANG H.J., CHEN C.S. Accessing the Carbofuran Degradation Ability of Cultures From Natural River Biofilms in Different Environments, Clean-Soil Air Water. 45 (5), 2017.

29. SNELL D.F., HILTON C.L. Encyclopedia of Industrial Chemical Analysis, Interscience Publishers New York, pages 1968.

30. TOMMASSEN G. On the correlation between Turbidity, Conductivity and COD, Technische Universiteit Delft, Germany, 2014.

31. ABUHAMED T., BAYRAKTAR E., MEHMETOGLU T., MEHMETOGLU U. Kinetics model for growth of Pseudomonas putida F1 during benzene, toluene and phenol biodegradation, Process Biochem. 39 (8), 983, 2004.

32. JIANG Y., WEN J.P., BAI J., JIA X.Q., HU Z.D. Biodegradation of phenol at high initial concentration by Alcaligenes faecalis, J Hazard Mater. 147 (1-2), 672, 2007.

33. GALLIZIA I., MCCLEAN S., BANAT I.M. Bacterial biodegradation of phenol and 2,4-dichlorophenol, J Chem Technol Biot. 78 (9), 959, 2003

34. SAHINKAYA E., DILEK F.B. Biodegradation of 4-chlorophenol by acclimated and unacclimated activated sludge - Evaluation of biokinetic coefficients, Environ Res. 99 (2), 243, 2005.

35. PATEL B.P., KUMAR A. Biodegradation of 2,4-dichlorophenol by Bacillus endophyticus strain: optimization of experimental parameters using response surface methodology and kinetic study, Desalin Water Treat. 57 (34), 15932, 2016.

36. DIZGE N., TANSEL B. External mass transfer analysis for simultaneous removal of carbohydrate and protein by immobilized activated sludge culture in a packed bed batch bioreactor, J Hazard Mater. 184 (1-3), 671, 2010.

37. QUAN X.C., SHI H.C., WANG J.L., QIAN Y. Biodegradation of 2,4-dichlorophenol in sequencing batch reactors augmented with immobilized mixed culture, Chemosphere. 50 (8), 1069, 2003.

38. KARGI F., EKER S. Kinetics of 2,4-dichlorophenol degradation by Pseudomonas putida CP1 in batch culture, Int Biodeter Biodegr. 55 (1), 25, 2005.

39. EKER S., KARGI F. Biological treatment of 2,4,6-trichlorophenol (TCP) containing wastewater in a hybrid bioreactor system with effluent recycle, J Environ Manage. 90 (2), 692, 2009.

40. UYSAL A., TURKMAN A. Effect of biosurfactant on 2,4-dichlorophenol biodegradation in an activated sludge bioreactor, Process Biochem. 40 (8), 2745, 2005. 
